\title{
Performance of broccoli (Brassica oleracea var. italica) under drip irrigation and mulch
}

\section{T. L. Thentu*, D. Dutta, D. Dutta Mudi and A. Saha}

Department of Agronomy, Bidhan Chandra Krishi Viswavidyalaya, Mohanpur-741252, Nadia (West Bengal), INDIA

*Corresponding author. E-mail: tulasiagrico318@gmail.com

Received: December 15, 2015; Revised received: April 23, 2016; Accepted: July 31, 2016

Abstract: Field experiment was conducted at Central Research Farm of Bidhan Chandra Krishi Viswavidyala, Gayespur, West Bengal during winter seasons of 2011-12 and 2012-13 to assess the comparative effectiveness of drip and conventional surface irrigation with and without mulch on growth and yield of broccoli. The experiment was laid out in split-plot design replicated thrice. Main plot treatments consist of four levels of irrigation such as surface irrigation with IW/CPE 1.0 and three drip irrigation at 1.0, 0.8 and 0.6 ETc (crop-evapotranspiration), and three mulch levels like no mulch, black polythene mulch and paddy straw mulch @ 5t/ha in sub-plots. The results showed that drip irrigation at 0.8 ETc showed significantly higher $(P=0.05)$ plant height $(45.69 \mathrm{~cm})$, no of leaves plant ${ }^{-1}$ $(17.66)$, leaf size index $\left(743.99 \mathrm{~cm}^{2}\right)$, plant spread $(89.94 \mathrm{~cm})$, curd diameter $(14.43 \mathrm{~cm})$ and marketable curd yield $\left(17.82 \mathrm{t} \mathrm{ha}^{-1}\right)$ of broccoli, which was at par with drip at $1.0 \mathrm{ETc}$. Minimum growth and yield was obtained with drip irrigation at 0.6 ETc in both the years. Similarly, significantly the highest $(P=0.05)$ plant variables and curd yield was obtained with use of black polythene mulch over paddy straw and no mulch treatments. However, drip irrigation at 0.6 ETc registered maximum water use efficiency of $117.31 \mathrm{~kg}$ ha- $\mathrm{mm}^{-1}$ and water saving of $38.43 \%$. The interaction effect showed that drip irrigation at $0.8 \mathrm{ETc}$ along with black polythene mulch produced significantly higher marketable curd yield. The experimental findings can be recommended for growing high value crop broccoli with water saving drip irrigation at ETc 0.8 along with plastic mulch technology in the water scarce regions of West Bengal.

Keywords: Broccoli, Drip Irrigation, Mulch, Water use efficiency, Yield

\section{INTRODUCTION}

Broccoli is a unique nutritious vegetable (El-Helaly, 2012). Its green inflorescence (curd) is rich in chlorophyll, ascorbic acid, vitamins and minerals (Fabek et al., 2012). The crop has been popularizing in the state West Bengal due to its higher market price and palatable taste than cauliflower. Broccoli is grown in winter season when normally there is low precipitation and high evapo-transpiration. Hence, its cultivation during the dry period usually requires high volume of irrigation water. Broccoli is a shallow rooted and high water demanding crop, mainly irrigated by furrow system. The crop requires frequent irrigation to keep the plant vigorous and higher yield of curd (Gomes et al., 2000). Farmers' practice for raising the crop with 5-7 irrigations by surface method leads to high water demand. However, availability of irrigation water in drier months is the main limiting factor to enhance crop productivity in several parts of the state. Further, the unscientific water management practices coupled with lack of proper water saving technologies can also lead to the reduction in crop yield (Sharma et al., 2013). Therefore, the adoption of micro-irrigation might help in increasing productivity of crop, irrigated area and water use efficiency (Akbari et al., 2009). Drip irriga- tion may be an alternative of conventional irrigation, especially for growing fruits and vegetables due to its precise and direct application of water in root zone (Imtiyaz et al., 2000). It provides the efficient use of limited water with increased water use efficiency. Therefore, the drip system not only saves water but also increases yield of fruits and vegetable crops compared to surface furrow irrigation (Karam et al., 2009). Mulching is a useful practice in rain-fed dry seasons for conserving moisture and nutrients in soil profile (Sharma et al., 2010). Organic mulches not only increase the yield but also add more organic matter and improve soil fertility as well as quality (Rao and Pathak, 1998). The use of polythene mulch is also beneficial in vegetable production due to control of weed incidence, reduce nutrient loss and improve hydrothermal regimes of soils (Singh, 2005). Black polythene mulch also controls weeds more successfully than other inorganic as well as organic mulches (Singh, 2005). The advantages of using plastic mulches for the production of high value vegetable crops have been recognized in the United States and the European countries. However, its usage has not been properly explored in India for high value vegetables like broccoli.

Quantifying the response of a high water requiring ISSN : 0974-9411 (Print), 2231-5209 (Online) All Rights Reserved @ Applied and Natural Science Foundation www.jans.ansfoundation.org 
vegetable broccoli to irrigation and mulch treatments is important for establishing the irrigation management strategies and water-savings. Earlier research shows that the yields and quality of the vegetable crops are improved through application of water by drip irrigation alone or along with different types of plastics and organic mulches (Tiwari et al., 2003). However, the information on the judicious use of irrigation water with different mulch materials in broccoli production is scanty in West Bengal. Therefore, the present study was attempted to evaluate the effect of irrigation applied through drip and surface furrow methods with and without mulch on growth, curd yield and wateruse efficiency of broccoli during winter season on sandy loam soil.

\section{MATERIALS AND METHODS}

Field experiment was conducted during winter seasons of 2011-12 and 2012-13 at Central Research Farm of Bidhan Chandra Krishi Viswavidyalaya, Gayeshpur, encompassing the New Alluvial Zone of West Bengal, $\left(22.1^{\circ} \mathrm{N}\right.$ latitude, $89.2^{\circ} \mathrm{E}$ longitude and $9.75 \mathrm{~m}$ above mean sea level) to study the response of various levels of irrigation under drip and surface systems and different mulches on growth, yield and water use efficiency of broccoli. The experimental soil was sandy loam in texture with $\mathrm{pH}$ 6.9 , organic carbon $0.54 \%$, available nitrogen 170.3 $\mathrm{kg} \mathrm{ha}^{-1}$, available phosphorus $15.1 \mathrm{~kg} \mathrm{ha}^{-1}$ and available potassium $159.6 \mathrm{~kg} \mathrm{ha}^{-1}$. The experiment was laid out in split-plot design replicated thrice. Main plots treatments consisted of irrigation scheduling, viz. surface irrigation at IW/CPE 1.0 and three drip levels at 1.0, 0.8 and $0.6 \mathrm{ETc}$ and sub-plots with three levels of mulch i.e., no mulch, black polythene mulch and paddy straw mulch@ 5 t/ha. The broccoli variety 'Green Magic' marketed by Syngenta seed company was tested as plant material. Broccoli seedlings were raised in nursery bed $\left(100 \mathrm{~m}^{2}\right)$ under the poly-house condition to protect seedlings from sunlight and rain and $10 \mathrm{~kg}$ FYM was mixed per square meter. Beds were drenching with Bavistin @ $2 \mathrm{~g} / \mathrm{l}$. The sowing was done in $5 \mathrm{~cm}$ apart lines and at a depth of 1-2 cm. Light watering by nursery cane was done immediately after seed sowing. Beds were cover with rice straw for 2-3 days which helped in germination. Regular watering, drainage and disease pest management was done. Seedlings of one month age were transplanted in main field on 25 th and $27^{\text {th }}$ of October at a spacing of $50 \mathrm{~cm} \times 50 \mathrm{~cm}$. The area of one plot was $12 \mathrm{~m}^{2}$ where 48 plants were sown in each plot. The recommended dose of $\mathrm{N}: \mathrm{P}_{2} \mathrm{O}_{5}: \mathrm{K}_{2} \mathrm{O}$ fertilizers were applied uniformly @ 150: 75: $75 \mathrm{~kg}$ $\mathrm{ha}^{-1}$ respectively (Kumar et al., 2013). The source of inorganic $\mathrm{N}: \mathrm{P}_{2} \mathrm{O}_{5}: \mathrm{K}_{2} \mathrm{O}$ fertilizers were urea, single super phosphate and muriate of potash respectively. Full dose of phosphorus and potassium were applied as basal in furrows near the root zone of the crop (band placement), whereas $\mathrm{N}$ was applied in 6 equal splits through drip irrigation (fertigation). For mulching, lateral drip lines having emitters at $50 \mathrm{~cm}$ distance were placed in each row of plants over which perforated black polyethylene film of $50 \mu$ thickness at $50 \mathrm{~cm}$ distance were spread manually on field and broccoli seedlings were transplanted such that each emitter is at the base of the seedling. In the case of paddy straw @ $5 \mathrm{t} \mathrm{ha}^{-1}$ treatment, paddy straw was placed as surface mulch about 10 days after transplanting when the seedlings were established in the field. During the experiment, the necessary cultural practices and plant protection measures were equally performed in all plots. The crops were harvested from $5^{\text {rd }}$ and $8^{\text {th }}$ January in 2011-12 and 2012-13, respectively.

Soil moisture studies were done during the entire crop period starting from sowing to final harvest of broccoli. Irrigation treatments were based on open pan evaporation data obtained from USWB (United State Weather Bureau) Class A Pan Evaporimeter installed near the experimental field. The pan was located on a wooden support at a height of $15 \mathrm{~cm}$ above the soil surface and readings were recorded daily. Lateral lines of $12 \mathrm{~mm}$ diameter were placed for each drip plot at $50 \mathrm{~cm}$ distance along the crop row. One dripper plant ${ }^{-1}$ was provided near the base of the plant at $50 \mathrm{~cm}$ interval over the lateral. The application of water in drip system was by the gravity force and the discharge rate of emitter was 1.8 litre hour ${ }^{-1}$ at a pressure of $1.2 \mathrm{~kg} \mathrm{~cm}^{-2}$. The volume of water for drip irrigation was calculated as per the following equation (Singh et al., 2009):

$\mathrm{V}=\Sigma(\mathrm{Ep} \times \mathrm{Kc} \times \mathrm{Kp} \times \mathrm{A} \times \mathrm{N}-\mathrm{Re} \times \mathrm{A})$

where, $\mathrm{V}=$ volume of water required for crop evapotranspiration $(\mathrm{ETc}) ; \mathrm{Ep}=$ daily pan evaporation $(\mathrm{mm}$ day $^{-1}$ ); Kc = crop factor; Kp = pan factor (using 0.75 value for this region); $\mathrm{A}=$ area of plot; $\mathrm{N}=$ number of days in a month for which the volume of applied water calculated; $\mathrm{Re}=$ effective rainfall $(\mathrm{mm}) ; \Sigma=$ signifies total of all the crop season. The irrigation frequency by drip system was every 3 days interval based on $0.6,0.8$ and 1.0 ETc. In surface method of irrigation, water was applied at IW:CPE 1.0, keeping $50 \mathrm{~mm}$ depth of irrigation. The number of surface irrigation was 3 in both the years of experiment during the crop period. Depth of irrigation was maintained with the help of par-shall flume. The total rainfall during the crop period was 19.5 and 20.2 $\mathrm{mm}$ in 2011-12 and 2012-13 respectively. The maximum and minimum temperatures during crop growth were 27.7 and $16.9^{\circ} \mathrm{C}$ in $201-12$ and 26.9 and $15.7^{\circ} \mathrm{C}$ in 2012-13.

The seasonal crop water use (WU) of broccoli was computed using the following water balance equation (Panigrahi and Srivastava, 2011): 
$\mathrm{WU}=\mathrm{P}+\mathrm{I}+\mathrm{Cp}-\mathrm{Dp}-\mathrm{Rf} \pm \Delta \mathrm{SW}$

Where, WU is the total water use $(\mathrm{mm}), \mathrm{P}$ is the precipitation $(\mathrm{mm}), \mathrm{I}$ is the total irrigation water applied $(\mathrm{mm}), \mathrm{Cp}$ is the contribution from capillary rise from groundwater $(\mathrm{mm}), \mathrm{Dp}$ is the deep percolation loss $(\mathrm{mm}), \mathrm{Rf}$ is the surface runoff loss of water $(\mathrm{mm})$ and $\Delta \mathrm{SW}$ is the change in soil water storage $(\mathrm{mm})$ from the entire crop root zone $(0-45 \mathrm{~cm})$ during the cropping period (just before planting and after harvesting). Since groundwater was below 3 meter during the crop growing period, $\mathrm{Cp}$ was assumed to be negligible. Dp was assumed neglected beyond $45 \mathrm{~cm}$ as it was considered that change in soil moisture storage below $45 \mathrm{~cm}$ were negligible and there was no loss of water through runoff (Rf) occurred since there was no heavy rainfall. Thus the above equation computed as $\mathrm{WU}=\mathrm{P}+\mathrm{I}+\Delta \mathrm{SW}$.

The growth attributes like plant height $(\mathrm{cm})$, no of leaves plant ${ }^{-1}$, leaf size index $\left(\mathrm{cm}^{2}\right)$ and plant spread (cm) were recorded treatment wise from 10 randomly selected plants of the each plot. Leaf size index is measured by multiplying the average length and breadth of three leaves in each plant. Data on curd diameter $(\mathrm{cm})$ was recorded from 10 plants of the plot. Three harvestings were taken and marketable curd yield was recorded at each harvest per plot in kilograms and it was then converted into yield per hectare. Water use efficiency (WUE) was calculated as the ratio of curd yield and total water used including irrigation water applied, effective rainfall and soil profile moisture contribution.

\section{RESULTS AND DISCUSSION}

Effect of irrigation on broccoli: The growth and yield contributing characters of broccoli such as plant height, number of leaves plant $^{-1}$, leaf size index , plant spread, curd diameter and curd yield were significantly influenced by drip and surface irrigation as well as the mulch treatments (Table 1). The mean data showed that drip irrigation at $0.8 \mathrm{ETc}$ produced significantly higher $(\mathrm{P}=0.05)$ plant height $(70.65 \mathrm{~cm})$, number of leaves plant ${ }^{-1}(38.40)$, leaf size index $\left(743.99 \mathrm{~cm}^{2}\right)$, plant spread $(89.94 \mathrm{~cm})$, curd diameter $(13.43 \mathrm{~cm})$ and curd yield $(17.59 \mathrm{t} \mathrm{ha}$ $\left.{ }^{1}\right)$ over drip irrigation at 0.6 ETc and surface irrigation at IW:CPE 1.0. However, this treatment was statistically at par with drip at 1.0 ETc, which showed the highest values of growth, yield attributes and also curd yield. Bora et al. (2014) also stated that drip irrigation at $80 \%$ evapo-transpiration (ET) of crop based on pan evaporation gave significantly higher plant height $(83.1 \mathrm{~cm})$, leaf area index (3.26), dry matter (38.4 g/plant), fruit weight (79.6 g/plant) and fruit yield (45.57 t/ha) compared with the surface irrigation in tomato crop on sandy loam soils of Punjab, India. The quantitative increase in growth parameters observed in this drip treatment might be due to the fact that the soil was kept near to the field capacity throughout the crop growth period in the active root zone, resulted in low suction which facilitated better water and nutrients uptake by the plants and also greater turgidity of cells with increase in available soil moisture leading to quicker cell division and enlargement. This experiment concluded that optimal application of water through drip irrigation on regular basis enhanced growth and yield promoting characters and consequently the curd yield of broccoli. The marked reduction in growth and yield parameters, and curd yield in drip irrigation at 0.6 ETc was particularly due to water stress under deficit irrigation which might have failed to fulfil the water requirement of the plant. Moister stress might have reduced cell division and cell elongation and hence plant growth was stunted. These finding are in conformity with Himanshu et al. (2013) who carried out field study during the winter season of 2009-2010 (December to March) on clay loam soil in Allahabad of India in order to evaluate the effect of irrigation methods and schedules on marketable yield, irrigation production efficiency and economic return of

Table 1. Effect of irrigation and mulch on growth, yield attributes and yield of broccoli (mean of two years).

\begin{tabular}{|c|c|c|c|c|c|c|}
\hline Treatment & $\begin{array}{l}\text { Plant height } \\
(\mathrm{cm})\end{array}$ & $\begin{array}{l}\text { No. of } \\
\text { leaves } \\
\text { Plant }^{-1} \\
\end{array}$ & $\begin{array}{c}\text { Leaf size } \\
\text { index } \\
\left(\mathrm{cm}^{2}\right) \\
\end{array}$ & $\begin{array}{c}\text { Plant } \\
\text { spread } \\
(\mathrm{cm})\end{array}$ & $\begin{array}{c}\text { Curd } \\
\text { diameter } \\
(\mathbf{c m}) \\
\end{array}$ & $\begin{array}{c}\text { Marketable } \\
\text { curd yield } \\
\left(\mathrm{t} \mathrm{ha}^{-1}\right)\end{array}$ \\
\hline \multicolumn{7}{|l|}{ Irrigation level } \\
\hline Surface irrigation IW/CPE 1.0 & 63.65 & 34.05 & 662.83 & 81.48 & 10.70 & 15.24 \\
\hline Drip 1.0 ETc & 71.69 & 39.22 & 758.42 & 92.41 & 14.43 & 17.82 \\
\hline Drip 0.8 ETc & 70.65 & 38.40 & 743.99 & 89.94 & 13.43 & 17.59 \\
\hline Drip 0.6 ETc & 62.00 & 32.94 & 637.32 & 80.94 & 9.72 & 14.74 \\
\hline $\operatorname{SEm}( \pm)$ & 1.21 & 0.43 & 12.41 & 1.51 & 0.36 & 0.27 \\
\hline $\mathrm{CD}(\mathrm{P}=0.05)$ & 3.74 & 1.33 & 36.00 & 4.43 & 1.11 & 0.84 \\
\hline \multicolumn{7}{|l|}{ Mulch } \\
\hline No mulch & 61.06 & 33.79 & 661.71 & 78.54 & 9.69 & 14.93 \\
\hline Back polythene mulch & 71.90 & 38.51 & 753.15 & 92.25 & 14.36 & 17.89 \\
\hline Paddy straw mulch & 67.99 & 36.27 & 687.10 & 87.78 & 12.04 & 16.23 \\
\hline $\operatorname{SEm}( \pm)$ & 1.25 & 0.46 & 13.28 & 1.64 & 0.40 & 0.31 \\
\hline $\mathrm{CD}(\mathrm{P}=0.05)$ & 3.86 & 1.42 & 39.42 & 4.85 & 1.23 & 0.92 \\
\hline
\end{tabular}


Table 2. Interaction effect of irrigation and mulch on curd yield of broccoli ( $t / h a)$ (mean of two years).

\begin{tabular}{lcccc}
\hline Irrigation level & \multicolumn{2}{c}{ Mulch } & \multirow{2}{*}{ Mean } \\
\cline { 2 - 4 } & No mulch & Black polythene mulch & Paddy straw mulch & \\
\hline Surface irrigation IW:CPE 1.0 & 13.59 & 17.18 & 14.95 & 15.24 \\
Drip 1.0 ETc & 15.89 & 19.64 & 17.94 & 17.82 \\
Drip 0.8 ETc & 16.28 & 19.00 & 17.50 & 17.59 \\
Drip 0.6 ETc & 13.95 & 15.75 & 14.53 & 14.74 \\
Mean & 14.93 & 17.89 & $\mathrm{I} \times \mathrm{M}$ & - \\
& $\mathrm{I}$ & $\mathrm{M}$ & 0.33 & $\mathrm{M} \times \mathrm{I}$ \\
$\mathrm{SEm}( \pm)$ & 0.27 & 0.31 & 1.02 & 0.35 \\
$\mathrm{CD}(\mathrm{P}=0.05)$ & 0.84 & 0.92 & & 1.09 \\
\hline
\end{tabular}

Table 3. Total water use, water use efficiency and water saving under different irrigation and mulch .

\begin{tabular}{lccccccc}
\hline Treatment & $\begin{array}{c}\text { Profile con- } \\
\text { tribution } \\
(\mathbf{m m})\end{array}$ & $\begin{array}{c}\text { Irrigation } \\
(\mathbf{m m})\end{array}$ & $\begin{array}{c}\text { Effective } \\
\text { rainfall } \\
(\mathbf{m m})\end{array}$ & $\begin{array}{c}\text { Total wa- } \\
\text { ter use } \\
(\mathbf{m m})\end{array}$ & $\begin{array}{c}\text { Curd } \\
\mathbf{y i e l d}(\mathbf{k g} \\
\left.\mathbf{h a}^{-\mathbf{1}}\right)\end{array}$ & $\begin{array}{c}\text { WUE } \\
(\mathbf{k g} \text { ha- } \\
\left.\mathbf{m m}^{-1}\right)\end{array}$ & $\begin{array}{c}\text { Water } \\
\text { saving } \\
(\boldsymbol{\%})\end{array}$ \\
\hline Irrigation level & & & & & & & \\
\hline Surface irrigation IW/CPE & & & & & & & \\
1.0 & 34.28 & 150.00 & 19.85 & 204.13 & 15240.00 & 74.64 & - \\
Drip 1.0 ETc & 34.67 & 118.25 & 19.85 & 172.77 & 17823.33 & 103.08 & 15.36 \\
Drip 0.8 ETc & 35.92 & 95.76 & 19.85 & 151.53 & 17593.33 & 116.05 & 25.77 \\
Drip 0.6 ETc & 36.84 & 68.99 & 19.85 & 125.68 & 14743.33 & 117.31 & 38.43 \\
Mulch & & & & & & & \\
\hline No mulch & 34.60 & 108.25 & 19.85 & 162.70 & 14927.50 & 94.69 & - \\
Black polythene mulch & 36.87 & 108.25 & 19.85 & 164.97 & 17892.50 & 111.15 & - \\
Paddy straw mulch & 34.82 & 108.25 & 19.85 & 162.92 & 16230.00 & 102.47 & - \\
\hline
\end{tabular}

broccoli under semi arid climate. However, this treatment was statistically at par with surface irrigation with IW:CPE 1.0. Therefore, it revealed that higher degree of deficit irrigation as well as excess irrigation was not at all conducive to promote the yield augmenting parameters of broccoli, leading to the decreased curd yield.

Effect of mulch on growth and yield of broccoli: The highest plant height $(71.90 \mathrm{~cm})$, number of leaves plant ${ }^{-1}(38.51)$, leaf size index $\left(753.15 \mathrm{~cm}^{2}\right)$, plant spread $(92.25 \mathrm{~cm})$, curd diameter (14.36) and curd yield (17.89 $\left.\mathrm{t} \mathrm{ha}^{-1}\right)$ was obtained with black polythene mulch treatment. This treatment was found superior to paddy straw mulch @ 5 t/ha and no mulch (control) (Table 1). The lowest growth, yield parameters and curd yield were registered with no mulch treatment. These results are in agreement with Kashyap et al. (2009) who conducted an investigation on sandy loam soil to find the effect of different irrigation regimes and polythene mulch on yield, quality and water used efficiency of the broccoli variety Pusa Broccoli KTS-1 at Assam Agricultural University, Jorhat. Paddy straw mulch showed better performance over control because of better soil environment created by mulching. The increase in curd yield due to black polythene mulching might occur from better moisture utilization by checking evaporation loss and fall of soil temperature during winter and lesser competition of weeds. This poly- thene mulch treatment produced 9.2 and $16.5 \%$ higher curd yield than straw mulch and no mulch respectively. Higher uptake of nutrients (N, P and $\mathrm{K})$ was due to higher temperature coupled with higher availability of soil moisture caused significant increase in dry matter accumulation and partitioning of assimilates under polythene mulching (Bora et al., 2014). Singh (2005) also reported complete elimination of weeds with the use of black polyethylene in tomato crop. Therefore, the use of black polythene mulch is a potential and hitherto untapped option for conserving soil moisture, reducing weed population and enhancing crop production efficiency by many folds in water demanding crop broccoli.

The interaction effect between irrigation scheduling and mulching was statistically analyzed (Table 2). It showed significantly higher $(\mathrm{P}=0.05)$ curd yield $\left(19.0 \mathrm{t} \mathrm{ha}^{-1}\right)$ with drip irrigation at $0.8 \mathrm{ETc}$ along with black polythene mulch. However, 0.8 ETc with black polythene mulch treatment combination was found statistically at par with drip irrigation at 1.0 ETc coupled with black polythene mulch. The minimum curd yield was registered with surface irrigation with no mulch, closely followed by drip irrigation 0.6 ETc without mulch. The greater water availability in drip irrigation at 0.8 or 1.0 ETc might have facilitated greater root growth and nutrients uptake and thereby produced higher yield of broccoli over other treatments. The interaction also stated that 
black polythene mulch performed better compared to paddy straw mulch irrespective of irrigation treatments. Therefore, application of water through gravity drip irrigation at 0.8 ETc and use of black polythene mulch may be beneficial to broccoli cultivators.

Water use efficiency and water saving: During two year of cropping seasons, the average values of effective rainfall, moisture contribution from soil profile and depth of irrigation water applied are given in Table 3 . The volume of irrigation application based on the measured evaporation values was initiated from first fortnight of November in both the years. The amount of water applied through drip at 0.6, 0.8 and 1.0 ETc was 68.99, 95.76 and 118.25 $\mathrm{mm}$ respectively, whereas the corresponding figure for surface irrigation with IW/CPE 1.0 was $150 \mathrm{~mm}$. The total water use and water use efficiency varied with the magnitude of water application, moisture contribution from soil profile and curd yield. The total water use during the crop period was maximum (204.13 mm) in surface irrigation. However, drip irrigation at $0.6 \mathrm{ETc}$ registered the highest water use efficiency of $117.31 \mathrm{~kg}$ ha-mm $\mathrm{mm}^{-1}$ and water saving of $38.43 \%$. This treatment was comparable to drip at 0.8 ETc which exhibited water use efficiency of $116.05 \mathrm{~kg} \mathrm{ha}-\mathrm{mm}^{-1}$. The corresponding values of water use efficiency for drip irrigation at $1.0 \mathrm{ETc}$ and surface irrigation IW/CPE 1.0 were 103.08 and $74.64 \mathrm{~kg}$ ha- $\mathrm{mm}^{-1}$ respectively. In spite of the highest water productivity and water saving with drip 0.6 ETc, the curd yield was lowest under this treatment as a consequence of deficit irrigation and moisture stress situations. These findings were confirmative with Kashyap et al. (2009) who found highest WUE $\left(4.11 \mathrm{t} \mathrm{ha} \mathrm{cm}^{-1}\right)$ under drip irrigation at $60 \%$ evaporation replenishment with mulch and the lowest

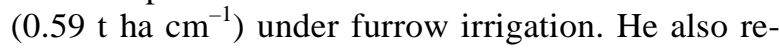
ported that water saving percentage under drip irrigated treatments was varied from 48.57 to $74.33 \%$ when compared with furrow irrigation in broccoli. However, the relatively higher water use efficiency under drip system as compared to surface irrigation was due to higher water uptake by the crop as a result of direct application of small amount of water in several splits into root zone without wetting the entire area and higher water distribution efficiencies in the soil profile. On the contrary, surface irrigation applying high volume water where the deep percolation loss is more, resulting in a considerable amount of water becomes unavailable to plants and thus lowers water use efficiency. Among the mulch treatments, black polythene mulch showed higher water use efficiency compared to others (Table 3). This might be due to lesser evaporative loss of water and weed free environment as well as higher curd yield under polythene mulched plots. Soil moisture con- servation due to poly mulching was also reported by Gupta and Acharya (1993).

It can be concluded from the study that drip irrigation at 0.8 ETc along with black polythene mulch gave the best results in terms of growth and yield of broccoli. Water use efficiency was recorded highest in drip at 0.6 ETc which was comparable with 0.8 ETc under the same level of mulch. Therefore, the water-saving drip technology and plastic mulch can be promoted for cultivation of broccoli in the water scarce regions of West Bengal.

\section{REFERENCES}

Akbari, M., Dehghanisanij, H. and Mirlatifi, S.M. (2009). Impact of irrigation scheduling on agriculture water productivity. Iranian Journal of Irrigation and Drainage. 1: 69-79.

Bora, N.J. and Babu, H.M. (2014). Drip irrigation and black polyethylene mulch pressure on development, yield and water-use efficacy of tomato. International Journal of Irrigation and Water Management . $1: 1-4$.

El-Helaly, M.A. (2012). Effect of nitrogen fertilization rates and potassium sources on broccoli yield, quality and storability. Research Journal of Agriculture and Biological Sciences. 8(4) : 385-394.

Fabek, S., Toth, N., Redovnikovic, I.R., Custic, M.H., Benko, B. and Zutic, I. (2012). The effect of nitrogen fertilization on nitrate accumulation, and the content of minerals and glucosinolates in broccoli cultivars. Food Technology Biotechnology. 50(2) : 183-186.

Gomes, R., Khan, M.S. and Islam, M.M. (2000). Effects of irrigation and nitrogen on broccoli in grey terrace soil. Bangladesh Journal of Agriculture Research. 25 : 423430.

Gupta, R. and Acharya, C.L. (1993). Effect of mulch induced hydrothermal regime on root growth, water use efficiency, yield and quality of strawberry. Journal of Agricultural Sciences. 64: 608-612.

Himanshu, S.K., Singh, A.K., Kumar, S. and Kalura, P. (2013). Response of broccolli to irrigation scheduling and methods under drip, sprinkler and surface irrigation. International Journal of Engineering and Advanced Technology. 2(4) : 777-782.

Imtiyaz, M., Mgadla, N.P., Chepete, B. and Mothobi, E.O. (2000). Yield and economic returns of vegetable crops under varying irrigation. Irrigation Science. 114(2) : 265-268.

Karam, F., Masad, R., Bachour, R., Rhayem, C. and Rouphael, Y. (2009). Water and radiation use efficiencies in drip irrigated pepper response to full and deficit regimes. European Journal of Horticultural Science. 74: 79-85.

Kashyap, S., Phookan, D.B., Baruah, R. and Bhuyan, P. (2009). effect of drip irrigation and polythenne mulch on yield, quality water use efficiency and economics of broccoli production. Indian Journal of Horticulture. 66 (3) : 323-325.

Kumar, M., Das, B., Prasad, K.K. and Kumar. P. (2013). Effect of integrated nutrient management on growth and yield of broccoli (Brassica oleracea var. italica) under Jharkhand conditions. Vegetable Science. 40 (1) : 117 120. 
Panigrahi, P. and Srivastava, A. K. (2011). Integrated Use of Water and Nutrients through Drip Irrigation in Nagpur Mandarin. Journal of Agricultural Engineering. 48 (3) : 44-51.

Rao, V.K. and Pathak, R.K. (1998). Effect of mulches on aonla (Emblica officinalis) orchard in sodic soil. Indian Journal of Horticulture. 55 : 27-32.

Sharma, A.R., Singh, R., Dhyani, S.K. and Dube, R.K. (2010). Moisture conservation and nitrogen recycling through legume mulching in rainfed maize (Zea mays)wheat (Triticum aestivum) cropping system. Nutrient Cycling in Agroecosystems. 87 (2) : 187-197.

Sharma, S., Patra, S. K., Roy, G. B. and Bera, S. (2013). Influence of drip irrigation and nitrogen fertigation on yield and water productivity of guava. The Bioscan. 8 (3) : 783-786.

Singh, R. (2005). Influence of mulching on growth and yield of tomato (Lycopersicon esculentum) in north India plains. Vegetable Science. 32 (1) :55-58.

Singh, R., Kumar, S., Nangare, D. D. and Meena, M. S. (2009). Drip irrigation and black polyethylene mulch influence on growth, yield and water-use efficiency of tomato. African Journal of Agricultural Research. 4 (12) : 1427-1430.

Tiwari, K.N., Singh, A., Singh, A. and Mal, P.K. (2003). Effect of drip irrigation on yield of cabbage under mulch and non-mulch conditions. Agriculture Water Management. $58: 19-28$. 